\title{
Comparative assessment of the food purchase program and the national school feeding program's impact in Ubá, Minas Gerais, Brazil
}

\author{
Leandro Gomes de Oliveira ${ }^{1}$ Mário Otávio Batalha ${ }^{2}$ Kleber Batista Pettan ${ }^{3}$
}

\begin{abstract}
${ }^{1}$ Grupo de Estudos e Pesquisas Agroindustriais (GEPAI), Departamento de Engenharia de Produção, Universidade Federal de São Carlos (UFSCar), Campus São Carlos, Rod. Washington Luís, Km 235, 13565-905, São Carlos, SP, Brasil. E-mail: leandrobaquim@dep.ufscar.br. Corresponding author. ${ }^{2}$ Grupo de Estudos e Pesquisas Agroindustriais (GEPAI), Programa de Pós-graduação em Engenharia de Produção, Departamento de Engenharia de Produção, Universidade Federal de São Carlos (UFSCar), São Carlos, SP, Brasil.

${ }^{3} J a p a n$ International Cooperation Agency (JICA), Brasília, DF, Brasil.
\end{abstract}

ABSTRACT: The Food Purchase Program (PAA) and the National School Feeding Program (PNAE) are the main trading programs of Brazil that promote a connection between the family farm and institutional markets. The case study portrayed in this article aimed to evaluate and compare the socioeconomic impacts generated by the PAA and PNAE among Ubá's family farmers in Minas Gerais. To do this, two tipes of questionnaires were applied to managers and farmers who participate in the programs and obtained data were analyzed by descriptive statistic methods and non-parametric tests (Mann-Whitney). Results showed that the two policies present positive socioeconomic benefits to family farmers, although the PNAE's producers income be higher and the food prices traded in PAA are superior. On the other side, having participated in the PAA and PNAE does not provide extra income arising from entry into new markets, which in theory could be the result of improving the quality of production, and does not promote the reduction in the use of fertilizers and pesticides.

Key words: family farm, food purchase program, national school feeding program.

Avaliação comparativa dos impactos do programa de aquisição de alimentos e do programa nacional de alimentação escolar em Ubá, Minas Gerais, Brasil

RESUMO: O Programa de Aquisição de Alimentos (PAA) e o Programa Nacional de Alimentação Escolar (PNAE) são os principais programas de compras institucionais do Brasil que promovem a conexão entre a agricultura familiar e os mercados institucionais. Um estudo de caso buscou avaliar e comparar os impactos socioeconômicos gerados pelo PAA e pelo PNAE aos agricultores familiares de Ubá, MG. Para isso, dois tipos de questionários foram aplicados aos gestores e aosprodutores dos programas e os dados foram analisados por meio de estatística descritiva e teste não paramétrico (Mann-Whitney). Os resultados mostram que ambas as politicas apresentaram beneficios socioeconômicos positivos, apesar da renda dos produtores do PNAE ser maior e os preços dos produtos no PAA serem superiores. Por outro lado, a participação no PAA e no PNAE não levou os agricultores a auferirem rendas extras advindas da inserção em novos mercados, que, em tese, poderia ser o resultado da melhoria da qualidade da produçãoe não promoveu a redução do uso de fertilizantes e pesticidas.

Palavras-chave: agricultura familiar, Programa de Aquisição de Alimentos, Programa Nacional de Alimentação Escolar.

\section{INTRODUCTION}

One of the main points of Brazilian public policies for strengthening family agriculture is development of institutional markets. Support policies, encouragement, and coordination of trading activities help the family farm (FF) to increase market access, considered one of the main obstacles to their development (DEFANTE et al., 2014). In this context, two programs have great national relevance: the Food Acquisition Program (PAA) and the National School Feeding Program (PNAE).The PAA was created in 2003 by Law n.10.696 and its objectives are to support people in social vulnerability with quality food that is exclusively purchased from FF or family enterprises. In addition, the PAA also aimed to help the formation of strategic public stocks to be traded at specific times (GRISA et al., 2011). This program comprises six operational modes: Purchase with Simultaneous Donation; Direct Buy; Support for Stock Formation; Incentive for Milk Production and Consumption; Institutional Purchase; and Seeds Acquisition. Each has a different way of access (individual or organizational), a different limit value/Statement of Fitness for PRONAF (DAP) (R\$8,000.00 to $\mathrm{R} \$ 20,000.00)$ and different resources origin (Ministry of Agrarian Development- MDA or Ministry of Social Development and Fight Against Hunger- MDS) (MDA, 2015). 
The official formalization of school meals as a social policy occurred in 1950 where government have promoted actions in order to improve food and nutritional conditions. The denomination National School Feeding Program happened in 1979 and its goals have been progressively developed over the years. Today PNAE intended to supply at least $15 \%$ of the daily food and nutrition needs of students in public schools during their stay in the classroom, contributing growth and development, learning, school performance, and formation of healthy eating habits. Besides the food and nutrition security, the program expands its focus to rural, local, and sustantable development by the Law n. $11.947 / 2009$ emphasizing that $30 \%$ of PNAE's operational resources are for purchasing food from FF(GONÇALVES et al., 2015). Resources for the PNAE's implementation come from the National Fund for Education Development (FNDE) and each producer may sell up R $\$ 20,000.00 / \mathrm{DAP} /$ year (MDA, 2015). Since their implementation, PAA and PNAE have been the subject of academic and government studies. In the literature, we can find assignments of PAA's evaluation (SOUZAESQUERDO \& BERGAMASCO, 2015) and PNAE's evaluation (TOYOYOSHI et al., 2013) in FF, as well as assessments of the combined effects (BELIK \& DOMENE, 2012). However, there is no comparative research contrasting the benefits achieved by one policy over the other. In this sense, it is very desirable to determine which one offers the most satisfactory results from the viewpoint of farmers, since FF have production scale problem (TRICHES \& SCHNEIDER, 2010) to provide food to two extra markets. The results of this study will assist farmers to make better decisions regarding the trading of their products. Thus, this article evaluates and compares the socioeconomic impacts generated by PAA and PNAE on the farmer-beneficiaries of Ubá region, Minas Gerais. Moreover, as complementary objectives, it presents the main aspects of the implementation and operation of these policies, as well as a profile of the producers who participate.

\section{MATERIALS AND METHODS}

This article has a descriptive and quantitative nature. A field survey was conducted in Ubá, Minas Gerais, between August and October, 2014. This municipality is located in Minas Gerais Forest Zone and its population is 101,519 inhabitants
(3.82\% reside in rural areas). Ubá's FF represents more than $80 \%$ (680) of farms, covering $50 \%(8,575$ hectares) of municipality area (IBGE, 2015a). Production of bananas, oranges, mangos, limes, beans, corn, cassava, and tomatoes stand out in the municipality's agriculture (IBGE, 2015b).

In 2014, 93 and 76 producers traded on PAA and PNAE, comprising Ubá's farmers and producers from neighboring municipalies. This selection criterion of respondents was intentional, due to convenience, and not probabilistic (FREITAS et al., 2000). Some producers could not be located, and others refused to fill out the questionnaire, resulting in a total sample of $81(87 \%)$ and $28(37 \%)$ PAA and PNAE's farmers, respectively.

The questionnaire was divided into two sections. The first consisted of open questions applied to program managers (year of program implementation in the city, the evolution of available resources, total number of $\mathrm{FF}$, total number of products traded by FF, total number of entities and people served, each traded product, the amount paid for each product in 2014 and complementary actions). The second section applied to FF addresses open questions (gender, age, marketing channels, the production unit location) and closed questions (Likert five-points):income; price paid for the product; production; food quality; access to rural credit; durable and nondurable goods; housing comfort; and use of pesticides.

\section{RESULTS AND DISCUSSIONS}

Implementation and operation of PAA and PNAE in Ubá

Although nationally institutionalized in 2003, PAA was only implemented in Ubá in 2008. Since the first agreement, the program has been operated by the Purchase with Simultaneous Donation mode and the trade occurs by Food Bank. PNAE's supply of FF products in Ubá began only in 2009 (Law n.11.947) and the trade occurs through the Association Airfield and region (ACAR).

In 2012, MDS transferred R $\$ 545,445.65$ to Ubá's PAA for the purchase of 188 tons of food, which represented an increase of $98 \%$ over the previous year (Figure 1). In subsequent years there were reductions in the volume of resources and products, because of the replacement of agreements between MDS and municipalities by Adhesion Therm (direct payment to producer via bank) and for updatingthe SISPAA system. In 2012, Ubá's PNAE received a total of $\mathrm{R} \$ 1,019,684.19$ (R\$879,588.00 from FNDE, and 
$\mathrm{R} \$ 140,093.19$ from cityhall), which $33.22 \%$ of this total was directed to the FF respecting the Law n. $11.947 / 2009$. In later years, the growing demands from schools because of number of students and the price paid for food caused gradual increase in total resources, resulting in the transfer of $\mathrm{R} \$ 681,785.22$ (40.97\% of the total) to FF through the acquisition of 263 tons of food.

Products traded in PAA total 39 types are intended to 34 entities of the municipality's social support network comprising 3,964 people in social vulnerability (Table 1). PNAE trade 27 types of foods, which are distributed to 67 public schools supplying nutrition needs of 6,976 students in Ubá.

Purchases are made through public calls no bidding, which makes marketing process more dynamic. The main foods traded in both programs are fruit, vegetables in natura, tubers, beans, animal products, and FF sell processed foods (e.g., cornmeal cake and marmalade) only to PAA (Table 2), because PNAE has specific suppliers for these foods, prioritizing mainly price and economies of scale. Bisedes that, quantity of food traded in PNAE is almost twice higher than PAA because the large number of students.

Farmers' profile and the socioeconomic impacts of $P A A$ and PNAE

Most farmers $(65.43 \%$ of PAA and $85.71 \%$ of PNAE) are male, with a mean age of 48 years old, and all trade their products at fairs, supermarkets, greengrocers, restaurants, agribusinesses, CEASA in Ubá and neighboring city, and also Uba's institutional markets. In addition, $65 \%$ of PAA producers and $46 \%$ of PNAE producers have their rural property in Ubá, although the headquarters of the programs being in this city, producers from Visconde do Rio Branco, Tocantins, Guidoval, Piraúba, Guarani, and Guiricema also participate in Ubá's PAA and PNAE because of proximity (maximum $40 \mathrm{~km}$ ). Lack of foods motivated the program managers to seek alternative sources of supply in locations near Ubá.

In Ubá's PAA and PNAE, each producer provided an individual food and the limits of annual participation are $\mathrm{R} \$ 8,000.00$ and $\mathrm{R} \$ 20,000.00$, respectively. Of the producers' total, $77 \%$ of PAA's producers and $89 \%$ PNAE's producers stated that their income has increased after starting trading within the studied policies, with no statistical difference between the samples (Table 3). However, the increase in the annual income of PNAE's producers $(\mathrm{R} \$ 8,970.85)$ was higher than that observed in farmers providing to PAA (R\$3,950.06), because of PNAE's demand is higher (Figure 1) and its have smaller number of farmers.

To effective and continuous trade, PAA and PNAE's price need to be attractive to producers. Thus, $57 \%$ of PAA's producers and $89 \%$ of PNAE's believe that food prices paid for their products under these programs are higher than in other regional

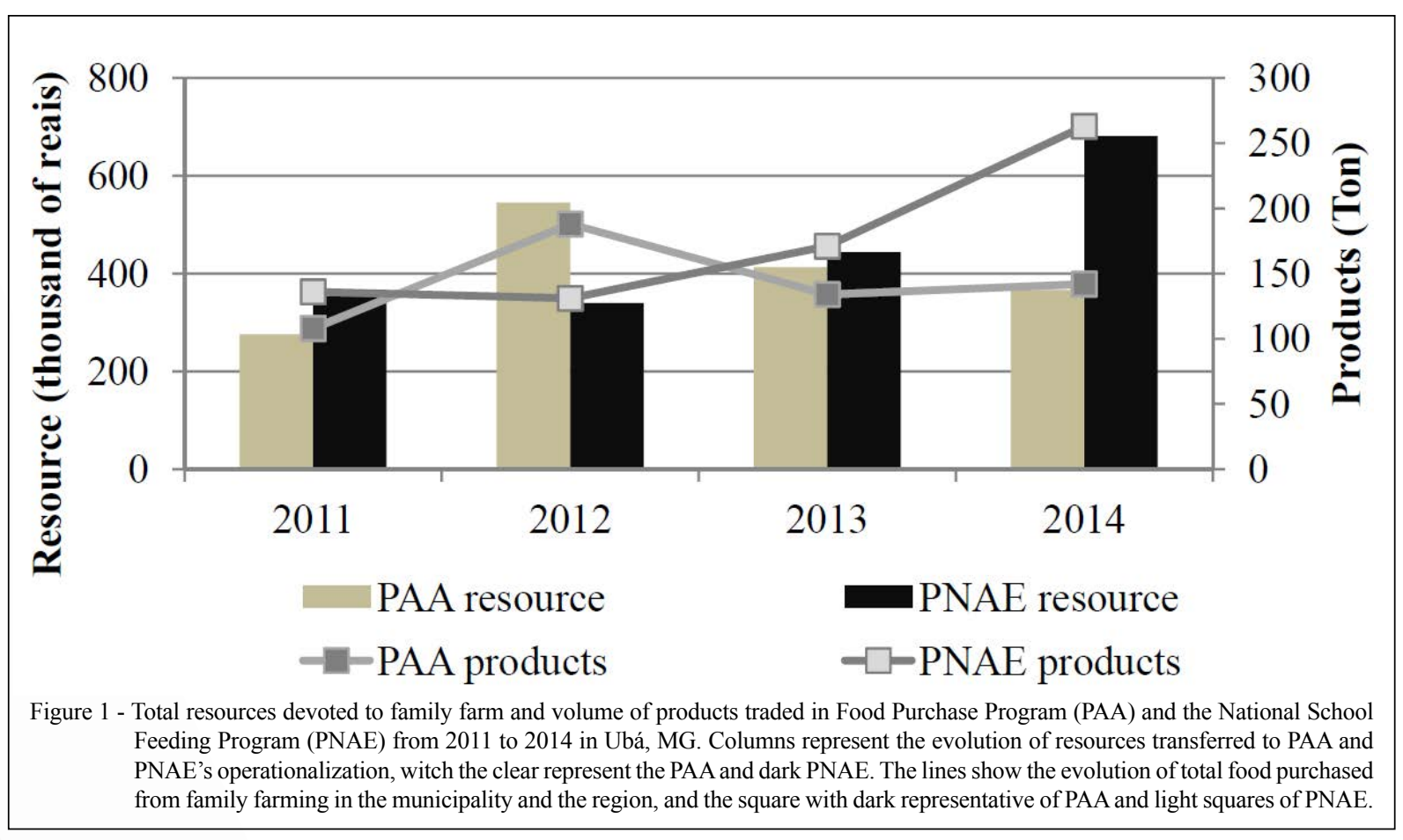

Ciência Rural, v.47, n.1, 2017. 
Table 1 - Entities and people served by Food Purchase Program (PAA) and the National School Feeding Program (PNAE) of Ubá in 2014.

\begin{tabular}{|c|c|c|c|}
\hline \multirow{10}{*}{ PAA } & Entities by type of activity & Number of assisted entities & Number of people assisted \\
\hline & Charities/social assistance & 11 & 1,199 \\
\hline & Support projects to children and adolescents & 6 & 495 \\
\hline & APAE and similar & 2 & 344 \\
\hline & Shelters/houses/hostels & 6 & 177 \\
\hline & Project to support the elderly & 1 & 138 \\
\hline & Religious projects & 2 & 342 \\
\hline & Hospitals & 1 & 113 \\
\hline & Cras/creas/peti/projovem & 5 & 1,156 \\
\hline & TOTAL & 34 & 3,964 \\
\hline \multirow{7}{*}{ PNAE } & Crèche/ Kindergarden & 20 & 1,126 \\
\hline & Preschool & 21 & 2,037 \\
\hline & Elementary school & 16 & 3,274 \\
\hline & Youth and Adult education-Elementary school & 6 & 433 \\
\hline & Youth and Adult education-High school & 1 & 16 \\
\hline & MaisEducaçãoProgramme & 3 & 90 \\
\hline & TOTAL & 67 & 6,976 \\
\hline
\end{tabular}

markets. However, PAA's food has higher prices than PNAE (Table 2), showing that management program don 't use the same base markets. Before 2013, PNAE sets its prices by using the reference of the PAA, although FNDE resolution n.26 defined the PNAE's prices will be established on the average values in the main regional markets. There are no statistical differences between the perceptions of PAA and PNAE's producers (Table 3), because price variation is only $\mathrm{R} \$ 0.15$.

According to ROSSI (2015), PAA provided expansion of production through insertion of new cultivars such as the increase of atual crops. In these sense results showed that $57 \%$ of the farmers trade with PAA and $61 \%$ of those who trade with PNAE increased their production and $56 \%$ and $49 \%$ of PAA's and PNAE's producers diversify their production to meet the specific programs demand. Farmers and local managers assert availability of management and practice course contributed to this.

PAA and PNAE provided social interactions among economic agents (farmers, managers and program staff, local and regional dealers), holding information exchanges that could create opportunities for new employment in alternative marketing channels. Despite this fact, $52 \%$ of PAA and $43 \%$ of PNAE, said that there was no entry into new marketing channels from entering the program and there are

Table 2 - Total amount and average price paid for the main products traded in the Food Purchase Program (PAA) and the National Schoo] Feeding Program (PNAE) of Ubá in 2014

\begin{tabular}{|c|c|c|c|c|}
\hline & ---------------- & -----------------. & 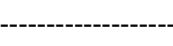 &  \\
\hline Products & Price/kg (R\$) & Quantity (kg) & Price/kg (R\$) & Quantity (kg) \\
\hline Banana & 1.65 & $13,391.55$ & 1.60 & $24,774.37$ \\
\hline Pumpkin & 1.60 & $9,474.45$ & 1.45 & $17,527.73$ \\
\hline Cassava & 1.30 & $7,230.96$ & 1.10 & $13,377.27$ \\
\hline Tangerine & 1.00 & $7,110.88$ & 0.95 & $13,155,13$ \\
\hline Beans & 4.60 & 5,376 & 4.45 & $9,945.60$ \\
\hline Cornmeal cake & 6.90 & $4,518.60$ & - & - \\
\hline Lettuce & 3.30 & $3,184.12$ & 3.15 & $5,890.62$ \\
\hline Tomato & 2.60 & $2,969.92$ & 2.55 & $5,494.35$ \\
\hline Free-range egg & 8.60 & $2,424.6$ & 8.50 & $4,485.51$ \\
\hline Cabbage & 3.10 & $2,284.30$ & 3.00 & $4,225.96$ \\
\hline Okra & 4.10 & $1,884.5$ & 4.00 & $3,486.33$ \\
\hline Marmalade & 7.70 & 598.24 & - & - \\
\hline
\end{tabular}


Table 3 - Mann-Whitney test applied in Food Purchase Program (PAA) and the National School Feeding Program (PNAE) socioeconomics variables.

\begin{tabular}{|c|c|c|c|c|c|c|}
\hline Variable & $\mathrm{U}$ & $\mathrm{Z}$ & p-level & $\mathrm{Z}$ - adjusted & p-level & $2^{*} 1$ sided - exact $p$ \\
\hline Income & 1061.000 & -0.5063 & 0.6126 & -0.7367 & 0.4613 & 0.6170 \\
\hline Price paid for the product & 1121.000 & -0.0902 & 0.9282 & -0.0972 & 0.9226 & 0.9313 \\
\hline Production & 947.000 & -1.2970 & 0.1947 & -1.4894 & 0.1364 & 0.1970 \\
\hline Diversification & 1061.500 & -0.5028 & 0.6151 & -0.5337 & 0.5935 & 0.6170 \\
\hline Access to marketing channels & 944.500 & -0.5061 & 0.6128 & -0.5590 & 0.5762 & 0.6149 \\
\hline Product quality* & 810.500 & 2.2436 & 0.0248 & 2.5571 & 0.0106 & 0.0243 \\
\hline Comfort in the house & 1071.500 & 0.4335 & 0.6647 & 0.5067 & 0.6123 & 0.6664 \\
\hline Durable and nondurable goods & 1107.000 & 0.1873 & 0.8515 & 0.2285 & 0.8193 & 0.8550 \\
\hline Rural credit & 1007.500 & -0.8773 & 0.3803 & -1.0021 & 0.3163 & 0.3824 \\
\hline Fertilizer application, pesticides & 989.500 & 1.0022 & 0.3163 & 1.1569 & 0.2473 & 0.3182 \\
\hline
\end{tabular}

Variables with superscripts (*) are statistically different to PAA and PNAE according to the Mann-Whitney test $(\mathrm{P}<0,05)$.

no statistical difference between PAA and PNAE regarding the perceptions of farmers (Table 3 ). Uba horticultural markets are already fully established and new possibilities of commercialization occurs only in other municipalities, which depending on location increase logistics costs infeasible trade.

PAA and PNAE have, as a principle, trading products of good quality. Delivery of food is carried out in the presence of a responsible fiscal authority, which certifies that the products are in acceptable conditions. To try to ensure this quality, Ubá'sPAA and PNAE, in addition to the productivity-enhancing courses, also provided quality assurance courses in food handling and transportation. Thus, there is a significant difference between the perceptions of producers about quality (Table 3), PNAE has a stricter “quality standard" (WITTMAN \& BLESH, 2015) prioritizing the appearance and uniformity of food.

Increase in income can improve the quality of life for producers. Considering the surveyed farmers, $65 \%$ of PAA and $68 \%$ of PNAE said their material goods increased and $60 \%$ of PAA producers and $57 \%$ of PNAE said they had improved the comfort of their houses after starting participation in policies. PAA and PNAE do not extend rural credit to farmers; however, the public extension service has direct contact with producers and it is able to develop projects that enable greater chances of access to credit. Thus, $32 \%$ of PAA's producers and $46 \%$ of PNAE's producers reported that access to rural credit increased after the policy. ROSSI (2015) asserts the request for higher loan volumes can be attributed to the expansion of crops, and the need for improvements in production systems, resulting in higher costs and investments. Although there were no statistical differences between the two groups (PAA and PNAE) (Table 3).

Agrocological and organic agriculture emerged in Brazil in eighties, with the growing awareness to preserve environment, occurred the expansion of the organic production system (CUNHA et al., 2010). PAA and PNAE encourage agroecological and organic food paying 30\% more than conventional products (FNDE, 2015). Despite that, interviews showed that $40 \%$ of the PAA producers and $54 \%$ of PNAE producers maintained the same quantity of agrotoxic and remain producers reduced because of insecticide's price.

\section{CONCLUSION}

PAA and PNAE are public policies that are presenting interesting impacts on the dynamics of FF providing positive socioeconomic benefits to Ubá's farmers and neighboring municipalities. Although, trading values are below the established limits, these programs have increased producer's income (PNAE's amount is almost twice higher) remunerating FF products like regional markets (PAA's prices are higher for all products). FF who produce smaller scale and more diversified products must sell to PAA, because its demand is smaller and comprises more variety. On the other hand, larger scale and smaller variety farmers should trade to PNAE, because larger number of people assisted. Processed foods are not included in products sold from FF to PNAE. Public call may include them incorporating new FF and maintaining cultural and dietary habits of municipaly. Both programs prioritize 
high quality products. According to WITTMAN \& BLESH (2015), standard of food quality in PNAE is more severe than PAA. In fact, there is a perception that program managers are stricter with the quality of products for PNAE prioritizing the appearance and uniformity of food. This may be a limiting factor for many farmers, since lack of storage and appropriate vehicles reduce considerably food quality. These programs improve the interaction between economic agents and encourage the production of organic; although, new market channels and organic products are not seen as a positive impact to most Ubá's producers. In theory it can be explained by the current situation of Uba's markets and the difficulty of producing food with no pesticides. The limitation of this study comes from the data collection method, producers' perception of socioeconomic impacts. Seeking to have more coherent vision of the problem, new studies may use specific methodologies to assess the impact of public policies. Also, this research was restricted to Ubá and region, future research may address the reality of other cities and compare the results. Besides that, PNAE's sample has significant percentage difference compared to PAA which in theory could explain the results. In addition, new researches may focus on political characteristics as operational, bureaucratic, and institutional barriers aspects, in order to better understanding of the reality of PAA and PNAE in Brazil.

\section{ACKNOWLEDGEMENTS}

The authors thank the Coordenação de Apereiçoamento de Pessoal de Nível Superior (CAPES) and the managers and farmers of PAA and PNAE of Ubá.

\section{REFERENCES}

BELIK, W.; DOMENE, S.M.A. Experiência de programas combinados de alimentação escolar e desenvolvimento local em São Paulo-Brasil. Agroalimentaria, v.18, n.34, p.57-72, 2012. Available from: $\quad<$ http://www.redalyc.org/articulo.oa?id=199222712005>. Accessed: Feb. 19, 2015.

CUNHA, E. et al. Organic food and educational actions in schools: diagnosis for health and nutrition education. Ciência \& Saúde Coletiva, v.15, n.1, p. 39-49, 2010. Available from: $<$ http://www.scielo. br/scielo.php?script=sci_arttext\&pid=S1413-81232010000100009>. Accessed: July 15, 2016. doi: 10.1590/S1413-81232010000100009.

DEFANTE, L.R.etal.Channel distribution of vegetablesnestingEstrela do Sul. Revista Brasileira de Administração Científica, v.5, n.1, p.200-213, 2014.Available from: <http://sustenere.co/journals/index. php/rbadm/article/view/SPC2179-684X.2014.001.0012>. Accessed: Jan. 15, 2015. doi:10.6008\%2FSPC2179-684X.2014.001.0012.

FNDE. Aquisição de produtos da agricultura familiar para alimentação escolar 2"edição - versão atualizada com a Resolução CD/FNDE $\mathbf{n}^{\circ}$ 04/2015. Brasília. Online. Available from: $<$ http://www.fnde.gov.br/arquivos/category/116-alimentacaoescolar?download $=9815$ : pnae- manual-aquisicao-de-produtosda-agricultura-familiar-para-a-alimentacao-escolar-2-edicao>. Accessed: June 26, 2016.

FREITAS, H.et al. O método de pesquisa survey. Revista de Administração (RAUSP), v.35, n.3, p.105-112, 2000. Available from: $<$ http://200.232.30.99/busca/artigo.asp?num_artigo=269>. Accessed: Nov. 15, 2014.

GRISA, C. et al.Contribuições do Programa de Aquisição de Alimentos à segurança alimentar e nutricional e à criação de mercados para a agricultura familiar. Agriculturas, v.8, n.3, p.34-41, 2011. Available from: <http://aspta.org.br/wp-content/uploads/2011/11/ artigo-6.pdf $>$. Accessed: May 23, 2016.

GONÇALVES,H.V.B. etal. Family farming products onmenus inschool feeding: a partnership for promoting healthy eating. Ciência Rural, v.45, n.12, p.2267-2273, 2015. Available from: <http://www.scielo. br/scielo.php?script=sci_arttext\&pid=S0103-84782015001202267>. Accessed: Mar. 19, 2016. doi: 10.1590/0103-8478cr20150214.

IBGE. Banco de dados agregados. Brasília, 29 dez. 2015a. Online. Available from: $<$ http://www.sidra.ibge.gov.br/bda/tabela/ protabl.asp?c $=1258 \& \mathrm{z}=\mathrm{t} \& \mathrm{o}=11 \& \mathrm{i}=\mathrm{P}>$. Accessed: Dec. 29, 2015.

IBGE. Produção Agrícola Municipal .Brasília, 29 dez. 2015 b. Online. Available from: <http://www.sidra.ibge.gov.br/bda/tabela/ listabl.asp?c=1613\&z=p\&o=29>. Accessed: Dec. 29, 2015.

MDA. Programa de Aquisição e Programa Nacional de Alimentação Escolar. Brasília, 28 dez. 2015. Online. Available from: <http://www.mda.gov.br/>. Accessed: Dec. 28, 2015.

ROSSI, F.R. Impactos socioeconômicos do programa de aquisição de alimentos em agricultores familiares de São Carlos-SP. Sociedade e Desenvolvimento Rural, v.9, n.2, p.1-29, 2015. Available from: <http://www.inagrodf.com.br/revista/index.php/ SDR/article/view/191/186>. Accessed: July 14, 2016.

SOUZA-ESQUERDO, V.F.; BERGAMASCO, S.M.P.P. Análise sobre o acesso aos programas de políticas públicas da agricultura familiar nos municípios do circuito das frutas (SP). Revista de Economia e Sociologia Rural, v.52, supl.1, p.205-222, 2015. Available from: $\quad<$ http://www.scielo.br/scielo.php?script=sci arttext\&pid=S0103-20032014000600011>. Accessed: May 24, 2016. doi: 10.1590/S0103-20032014000600011.

TRICHES, R.M.; SCHNEIDER, S. School feeding and family farming: reconnecting consumption to production. Saúde\&Sociedade, v.19, n.4, p.933-945, 2010. Available from: $\quad<$ http://www.scielo.br/scielo.php?script=sci_arttext\&pid $=$ S0104-12902010000400019>. Accessed: July 13, 2016. doi: 10.1590/S0104-12902010000400019.

TOYOYOSHI, J.Y. et al. Evaluation of the acquisition of food items from family farm for school meals. O Mundo da Saúde, v.37, n.3, p.329-335, 2013. Available from: <http://www.saocamilo-sp.br/ pdf/mundo_saude/106/1829.pdf $>$. Accessed: May 24, 2016.

WITTMAN, H.; BLESH, J. Food sovereignty and fome zero: connecting public food procurement programmes to sustainable rural development in Brazil. Journal of Agrarian Change, 2015. In press. Available from: <http://onlinelibrary.wiley.com/ doi/10.1111/joac.12131/abstract $>$. Accessed: May 24, 2016. doi: 10.1111/joac.12131. 